\title{
Faculty Members' Information and Communication Technology Skills after a Web 2.0 Tools Activity Course
}

\author{
Hanadi J. Buarki
}

\begin{abstract}
The aim of this research was to assess the Department of Library and Information Science (DLIS); College of Basic studies (CBS) Kuwait, faculty members' usefulness of a web 2.0 tools activity course and how it affected their attitude towards Information and Communication Technology (ICT) use. The faculty members who had applied to the ICT training course were taught and then surveyed after its completion.

The results conveyed a positive overall attitude towards the course; the faculty found the course helpful in work/non-work related tasks, gained adequate ICT skills, understood the course clearly, thought it was interesting, would recommend it to colleagues and they were interested to take another related course in Kuwait/abroad.

Departments and colleges of different disciplines can make use of this research to assess their faculty members' ICT skills to find out the benefits gained and to help them in professionally developing their faculty ICT skills regularly.
\end{abstract}

Index Terms-ICT Skills, professional development, faculty members, web 2.0.

\section{INTRODUCTION}

Morentin, Amenabar and Lareki emphasised that it is crucial to teach new digital technologies to faculty members in order for them to adjust to changing educational processes [1]. Thanuskodi stressed that information and communication technology (ICT) tools and devices have an important role to help produce and transmit new information and knowledge easily and rapidly for its users [2]. According to Göktaş, Yıldırım and Yıldırım ICT increases the quality of teaching, and facilities the process of instructing [3]. ICT is also essential for improving and adjusting the educational system/methods of learning in higher education [4].

In Kuwait ICT education is being promoted by the Government of Kuwait as something to be employed in schools and Higher Education (HE); universities are employing the use of ICT in their curricula; and in schools, lessons are being taught in this subject. Although the literature shows some negative attitudes towards ICT use and its implementation in Kuwait [5], [6], a recent study has provided evidence of a readiness and some positive factors towards ICT use [7].

The aim of this research was based on the realization that there was an information literacy gap among the faculty members at the Department of Library and Information Science (DLIS), Kuwait. Those employed twenty years ago

Manuscript received April 23, 2014; revised July 7, 2014.

Hanadi J. Buarki is with Public Authority for Applied Education and Training, Kuwait (e-mail: hjbuarki@hotmail.com). or more had very basic ICT skills or even were computer illiterate and those recently employed generally had very good levels of ICT skills and qualifications. Both groups are $\mathrm{PhD}$ and masters holders.

Having two distinct groups of users; one very ICT literate and one less so enabled their respective skills and needs to be identified and the affect that the ICT training had on the development and acquisition of these skills. Perhaps understandably, it was a challenge to encourage those that were historically less skilled in ICT to adopt and apply the use of this technology, and hence update their skills.

\section{LITERATURE REVIEW}

Introducing ICT technology into an established computer network is a relatively easy process, as the literature describes it [8]. However, it is not just the integration of tools, hardware, software and the enabling technology, but the challenging process to both the employer and its employees (in our case the institution and its faculty) to provide suitable training programs and encourage their positive uptake and consequent constructive use of the ICT skills acquired.

Problems of integration as Altun, Kalayc1 and AVCI explains them are the lack of resources and support from administrators; hardware and software related problems; lack of faculty and staff motivation, and faculty's often unwillingness to develop their ICT skills. Their findings confirmed that ICT integration consists of various stages such as raising awareness, breaking resistance, giving in-service training, and motivation. And that people working with ICT should be aware of new technologies as they emerge [9].

Today institutions are increasingly stressing the value and use of ICT and that faculty members should be making use of it in the educational process. Usluel, Aşkar and Baş confirmed a relative lack of this use of ICT in the educatuional process by collecting data from 814 faculty members in 22 universities in Turkey. They proved that faculty members use ICT mainly for communication, searching for information; their least use was for publishing their lecture notes, course assignments and projects. The importance of using web tools effectively was also stressed. It similarly stated that universities should have policies which regulate the use of ICT in order to develop faculty members' skills and provide technical and educational support [10].

In research conducted in India on 280 faculty members at the Annamalai University, different departments had their use of ICT assessed for information creation. Results indicated that the faculty members preferred to use the Internet (83\%) and personal computers (75\%) respectively 
for information search. Faculty members (76\%) also used ICT tools to search for relevant materials and to create new information. It was concluded that all the faculty members at the university knew about ICT; they agreed to its use and implementation to help progress education at the university; ICT plays an important role to create new information and knowledge; and that its transmission has become very easy and fast with the use of ICT tools and devices [2].

A similar research in Pakistan highlighted that the integration of ICT into education depends on the accessibility of the ICT resources. Hence, without the availability of hardware, software and computers teachers will not access nor use ICT. It showed that the interest of the 224 faculty members surveyed has positive effect on ICT practice in academic activities. It was recommended that ICT usage should be extensively practiced, faculty members should be educated for its use and that ICT should be considered within the strategies of universities [4].

Morentin, Amenabar and Lareki identified the possible differences in faculty's attitudes toward the use of new technological resources. A total of 472 faculty members at University of the Basque Country, Spain, were surveyed. The results indicated that the faculty's highest level of knowledge of ICT tools was the understanding of basic technological resources (such as word processors, the use of e-mail and computers in the classroom). The most frequent training strategies in evident use were those where faculty taught themselves how to use these basic ICT technologies. The faculty's preference of the training place was that it should be close to their working environments. They recommended the establishment of a system to frequently identify the faculty's training needs; and that the training needs should be tailored according to their demand and preference [1].

Awan stated that teacher (four teachers were surveyed from schools in UAE) attitudes can be altered positively after "providing them with supported learning experiences" which in turn can be employed to develop ICT curricula. The results showed that where teachers had a positive attitude towards ICT training, they noticed that there was an association between ICT training and their teaching practice where they felt confident in the use of ICT. The findings demonstrated that training teachers and providing them with learning experiences affects their attitudes positively towards ICT use in teaching [11].

Whereas, ICT integration became a preference among some faculty, it was a must to others. Shuva, in Bangladesh, illustrated that without comprehensive training to give ICT expertise it is unreasonable to consider the integration of it into the curriculum where it is hoped to bring positive results. The author suggested that the faculty should have an ICT training course after which they will be expected to "create learning experiences in which students use ICT to research, interpret, analyze, communicate and represent knowledge; deploy learning technologies to assist students develop critical learning skills; design learning experiences in which students actively use ICT to research, interpret, analyze, communicate and represent knowledge and understanding; and help students become lifelong learners" [8]. It was stressed that several barriers hinder the integration of ICT into the curriculum such as lack of infrastructure support; lack of suitable planning and administration; lack of professional training for faculty members and lack of finance. It was recommended to form an ICT Curriculum Integration (ICTCI) task force that would work to integrate ICT into the university curriculum; ensure the availability of adequate infrastructure and equipment; faculty should be supported to design teaching methods that are compatible with the different learning styles of ICT; and providing financial support to integrate ICT into the curriculum [8].

The above literature showed the importance of ICT integration and training [2]-[4], [9], [10]. Faculty members had positive attitudes towards ICT use and training [4], [11]. It was practiced by faculty members to communicate, search and create new information [2], [10]. There were problems providing ICT such as lack of resources, lack of infrastructure, lack of suitable planning and administration, lack of professional training, lack of finance, lack of faculty motivation and some staff problems where they were sometimes unwilling to develop their skills [4], [8], [9]. Awareness was the first step towards ICT integration [9]. It was also suggested to have policies/strategies regulating ICT use [4], [9], giving in-service training to faculty members and motivating them for its use [9]. In addition to providing a customized system to know and understand their training needs [1].

\section{RESEARCH SETTING}

The research was conducted at the DLIS, established in 1977 in Kuwait at the CBE, Public Authority for Applied Education and Training (PAAET). There are 28 teaching faculty members, 15 training faculty members and 1800 students at the department. The department has five ICT labs each equipped with 20 computers and data show. The teaching and training faculty all are provided with desktop/laptops and free WIFI at their offices/homes. The department has its own web page provided through a link on the PAAET's web site. It provides departmental information on courses offered and of the teaching and training faculty members. Faculty email, registration services, and students' services are made available through PAAET's web site.

Having all the above mentioned facilities available, it was expected that all the faculty members had at least basic ICT skills to perform daily routine/course work procedures on their own. What was recognised was that only a relatively small number had ICT skills and therefore were making use of what was offered at the department. Hence, there was a need to conduct the current research.

An ICT training session was planned to be conducted to the teaching and training faculty at the DLIS. The session was the first of its kind to be organised in the last ten years. The researcher had recognised the need of offering such a course to update the faculty ICT skills and encourage them to its use in their daily activities and teaching.

The preparation for the course took about six months. It started by investigating the need to conduct the course by asking the faculty members about their need and opinion of organising such a course. Ten $(50 \%)$ teaching and training faculty members out of 20 (they were teaching/training students on ICT courses) showed their interest in attending 
the course if it was conducted locally. One member was pessimistic that the procedures to arrange and conduct a course of this kind would take too long and might end up without actually happening.

Nevertheless, the researcher had permission to organise the course and started searching for a provider. After searching Google using the terms ICT education/skills and professional development (PD) courses, a number of results were obtained. About three providers were contacted to conduct the course in Kuwait. Two showed their interest. The researcher compared the two offers and presented them to the faculty members. A decision was made to choose the one that offered more activities and was flexible to meet the needs of the department.

Edutechteacher was chosen with regard to the following issues:

- The presenter offered a three day hands on training course that was flexible to the needs of the faculty.

- The presenter also indicated that the offered course would suit all of the ICT skill levels of the faculty.

- Edutechteacher provides courses such as "Best Web Tools for Teaching" and "The Flipped Classroom" that are approved by Framingham State University for graduate credit. These programs and others are also presented at schools and colleges in the United States, China, Czech Republic, Poland, Singapore and Taiwan [11].

- The presenter had been invited to Singapore by the Ministry of Education as an "Outstanding Educator in Residence" and had received an award in Asia for leadership and innovation in educational technology [11]. The training provider (Edtechteacher) was contacted officially to conduct the course and provide a proposal of daily activities. The researcher was asked to provide information on participants' ICT level (for example if they had basic keyboard, hardware and software usage skills), number of participants, their English language proficiency level and their academic disciplines. Also what are the courses they teach and the courses level of instruction (introductory or advanced).

After one week Edtechteacher provided a five day agenda for the course. Since the faculty had busy schedules to cover, Edtechteacher was asked to reduce the course to three days. Edtechteacher then provided the agenda of the three-day detailed daily programme course. Reducing the course to three days would also reduce the cost, since the department was restricted to a limited budget. Nevertheless, it was possible to conduct only one three day course with a number of 20 attendees and one instructor.

The course participants were chosen from a total of 43 members, due to the following set criteria:

- English language proficiency, since the course instructor was an American native speaker.

- The teacher/trainer (either teaches or trains students on ICT use) was assumed to have at least ICT basic skills.

- A willingness to attend the three day ICT intensive course.

- The course started on $10^{\text {th }}$, December, 2012 and lasted for three days. The daily session started daily at 9:00 am and ended at 4:00 pm, with two breaks in between. Technical help was provided whenever needed for trouble shouting. In day one, participants applied Web 2.0 tools and used educational applications in lecturing. They learned to create significant activities that will meet the needs of their students. In day two, they learned to use technology to deliver content in formats where students can work individually on their own; students will come to class ready to do activities that require the teacher's assistance. And in day three, they developed effective assessment using 2.0 strategies and examined how it differs from a traditional assessment. Moreover, the course blended presentations and tutorials with hands-on activities, the use of some tools and platforms, such as Google Docs, Animoto, Socrative, Aviary, Audioboo, Quizlet, VoiceThread, Twitter and other Web 2.0 tools, see Fig. 1. Participants also learned about educational applications such as Notability, Explain Everything, and iMovie.

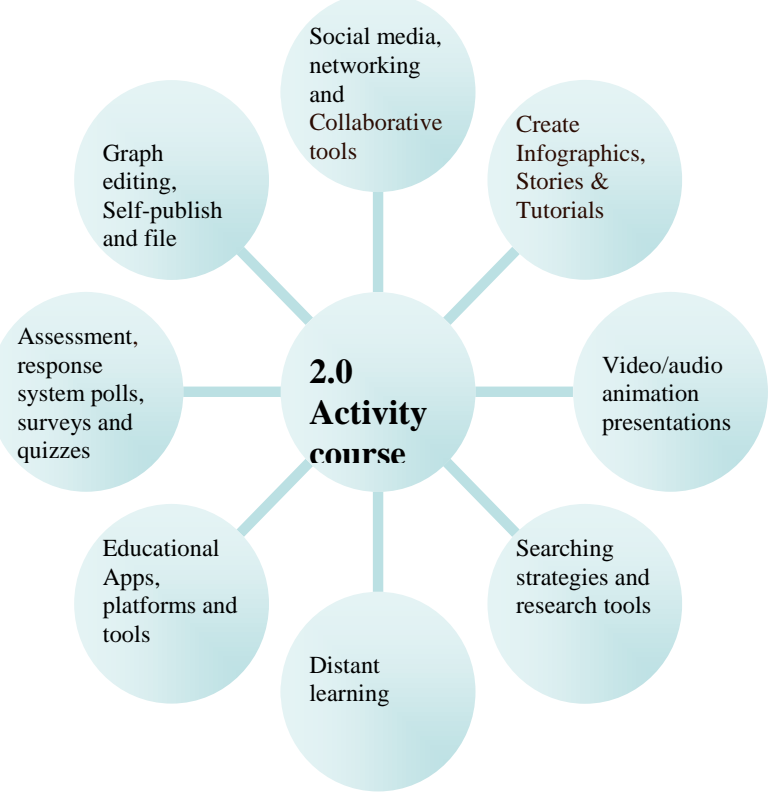

Fig. 1. 2.0 activity course main components.

\section{METHODOLOGY}

An online questionnaire, adopted from a study by Awan [12], was customized and emailed to the faculty that had attended the ICT 2.0 activity course. The questionnaire aim, instructions and link were provided. The questionnaire consisted of four sections. Section one Course needs, consisted of twelve questions; section two ICT use, consisted of fifteen questions; and section three Faculty's opinion, consisted of eleven questions.

\section{A. Research Sample}

A nonprobability purposive sampling technique was conducted to select the faculty members. The sample was representative based on certain selection criteria [13], mentioned above (Section III. Research Setting), in this case participants of the course had the chance to participate. Therefore, the research sample consists of twenty (fifteen teaching and five training) faculty members from the DLIS that have took the ICT 2.0 activity course. An invitation was emailed to the participants to kindly follow the provided link and fill out the questionnaire. One week later another reminder was sent to those who did not answer the questionnaire. After two weeks all the faculty members had emailed the questionnaire back, except for two. The number 
of participants was 18 out of the 20 .

\section{Data Collection}

Data collection started as the researcher took part in the ICT training course and observed the participants' interaction during the course. They showed interest during the training; they were keen to attend daily from 9:00 am to 4:00 pm; they would ask questions and participate in discussions. And participants always asked for the lecturer's help when they needed it.

However, the primary data collection for the online questionnaire was done during April, 2013. Nearly five months after the ICT course. This was intended to give the participants time to make use of the programmes and skills they had gained through the ICT course.

\section{RESUlTS AND ANALYSIS}

The results of the questionnaire were recorded through the use of categorical choices in questions one to five and the use of a five-point scale ranging from "Strongly Agree" to "Strongly disagree" in questions six to eight.

\section{A. Personal Information}

As previously mentioned, the research sample was chosen from 43 faculty members representing the DLIS teaching and training faculty members. The 18 faculty members' gender consisted of eleven $(60 \%)$ male and seven $(40 \%)$ female. The preponderance of males in the sample reflected the composition of the staff, where $(70 \%)$ of the faculty members at the DLIS are males.

Of the 18 faculty members, six were 31 to 40 years old, six were 41-50 years old and the rest six were 51 and over. None were " 30 or less" years old, this could be related to the fact that there had been no new recent recruits to the DLIS and/or that new employees are required to have higher degrees/qualifications (such as MLIS/PhD or/and experience), which is usually found with more senior staff.

The faculty members had three different academic degrees. Fourteen $(78 \%$ ) had a $\mathrm{PhD}$, three $(17 \%)$ had a MLIS (this is due to the old employment system at PAAET that permitted the employment of all university qualifications as faculty members, regardless of their degree at the same job) and one faculty member had a BA/BS. Analyzing the faculty members according to their employment status showed that there was one $(6 \%)$ professor among the 18 faculty members, two $(11 \%)$ associate professors, eleven $(61 \%)$ assistant professors and four $(22 \%)$ training faculty. The majority of the faculty members $(61 \%)$ being assistant professors could be to the reasons that most of them are recent graduates and had come back from their post studies, as they were on scholarships.

The faculty members varied in their length of working experience five had more than 15 years of experience, only one had 11-15 years, three had 6-10 years and the majority $(50 \%)$ had 5 or less years of experience. This indicates that half of the faculty members were less experienced (5 or less years of experience) but were nonetheless candidates to take part in the course and then the questionnaire.

\section{B. Course Need}

Table I illustrates the results of the respondent's statements from the questionnaire about their training needs from the course. The statements were divided into three sections. Section one showed the faculty members' ICT skills "level". As stated the majority of the faculty had basic and appropriate ICT skills, on the other hand almost $50 \%$ did not have advanced ICT skills. In section two the ICT 2.0 activity course need "reasons" were stated. The faculty members were interested to know and learn more about ICT and its use. They were also willing to develop and update their ICT skills. The third section stated the faculty members' course need in "teaching and training". It is clear from their responses that the course had updated their skills and they were ready to apply them in their teaching and educational processes, seeing TABLE I.

TABLE I: ICT SKILLS QUESTIONNAIRE AFTER THE 2.0 COURSE - COURSE NEED

\begin{tabular}{|c|c|c|c|c|c|}
\hline की. & $\#$ & Statement & $\begin{array}{l}\text { Strongly } \\
\text { agree/ } \\
\text { Agree }\end{array}$ & 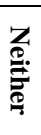 & $\begin{array}{l}\text { Disagree } \\
\text { /strongly } \\
\text { Disagree }\end{array}$ \\
\hline \multirow{3}{*}{ 胥 } & 1 & I know basic ICT skills & 14 & 2 & 2 \\
\hline & 2 & $\begin{array}{l}\text { I have appropriate ICT } \\
\text { skills to apply }\end{array}$ & 17 & 1 & 0 \\
\hline & 3 & I have advanced ICT skills & 8 & 2 & 8 \\
\hline \multirow{6}{*}{ 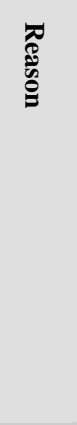 } & 4 & $\begin{array}{l}\text { I took the course to know } \\
\text { more about ICT }\end{array}$ & 16 & 2 & 0 \\
\hline & 5 & $\begin{array}{l}\text { I was interested to learn } \\
\text { more ICT use from the } \\
\text { course }\end{array}$ & 18 & 0 & 0 \\
\hline & 6 & $\begin{array}{l}\text { I would like to develop my } \\
\text { skills as everyone else is }\end{array}$ & 18 & 0 & 0 \\
\hline & 7 & $\begin{array}{l}\text { I need to update my ICT } \\
\text { skills regularly }\end{array}$ & 18 & 0 & 0 \\
\hline & 8 & $\begin{array}{l}\text { I need to develop my ICT } \\
\text { skills for my PD }\end{array}$ & 18 & 0 & 0 \\
\hline & 9 & $\begin{array}{l}\text { ICT training is a priority to } \\
\text { me }\end{array}$ & 16 & 2 & 0 \\
\hline \multirow{4}{*}{ 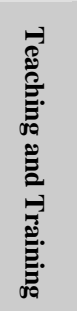 } & 10 & $\begin{array}{l}\text { I need to keep up to date } \\
\text { with ICT development }\end{array}$ & 18 & 0 & 0 \\
\hline & 11 & $\begin{array}{l}\text { I need to develop my ICT } \\
\text { skills to apply it in teaching }\end{array}$ & 18 & 0 & 0 \\
\hline & 12 & $\begin{array}{l}\text { I was convinced of its } \\
\text { educational benefits }\end{array}$ & 18 & 0 & 0 \\
\hline & 13 & $\begin{array}{l}\text { I feel providing ICT } \\
\text { training is appropriate to } \\
\text { my teaching }\end{array}$ & 17 & 1 & 0 \\
\hline
\end{tabular}

\section{ICT Use}

Table II defines the faculty members' ICT use. Section one showed their "approach to ICT use". Although some were afraid to use new ICT tools, the majority found approaching ICT effective and easy and could teach students in its use. In section two the "course outcomes of ICT use" were stated. The faculty members agreed that "the course encouraged me (them) to use ICT in collaboration", "increased my (their) ICT use", and they have "learned new ICT terminology". They also have confirmed, in section three "tools/programs", that the course has helped them to use new ICT 2.0 resources/tools such as online surveys, new search engines, and Google docs, Fig. 1. However, most (more than 50\%) have used/will use these programs in their classes. In addition, a relatively small number (four only) of the faculty used Socrative to create Polls and surveys and some (five only) 
used Refseek to search for academic research. More than half of the faculty started using Google Docs to share and create documents and the same number also have used applications on IPad/IPhone with their students.

\section{TABLE II: ICT SKILLS AFTER THE WEB 2.0 COURSE - ICT USE}

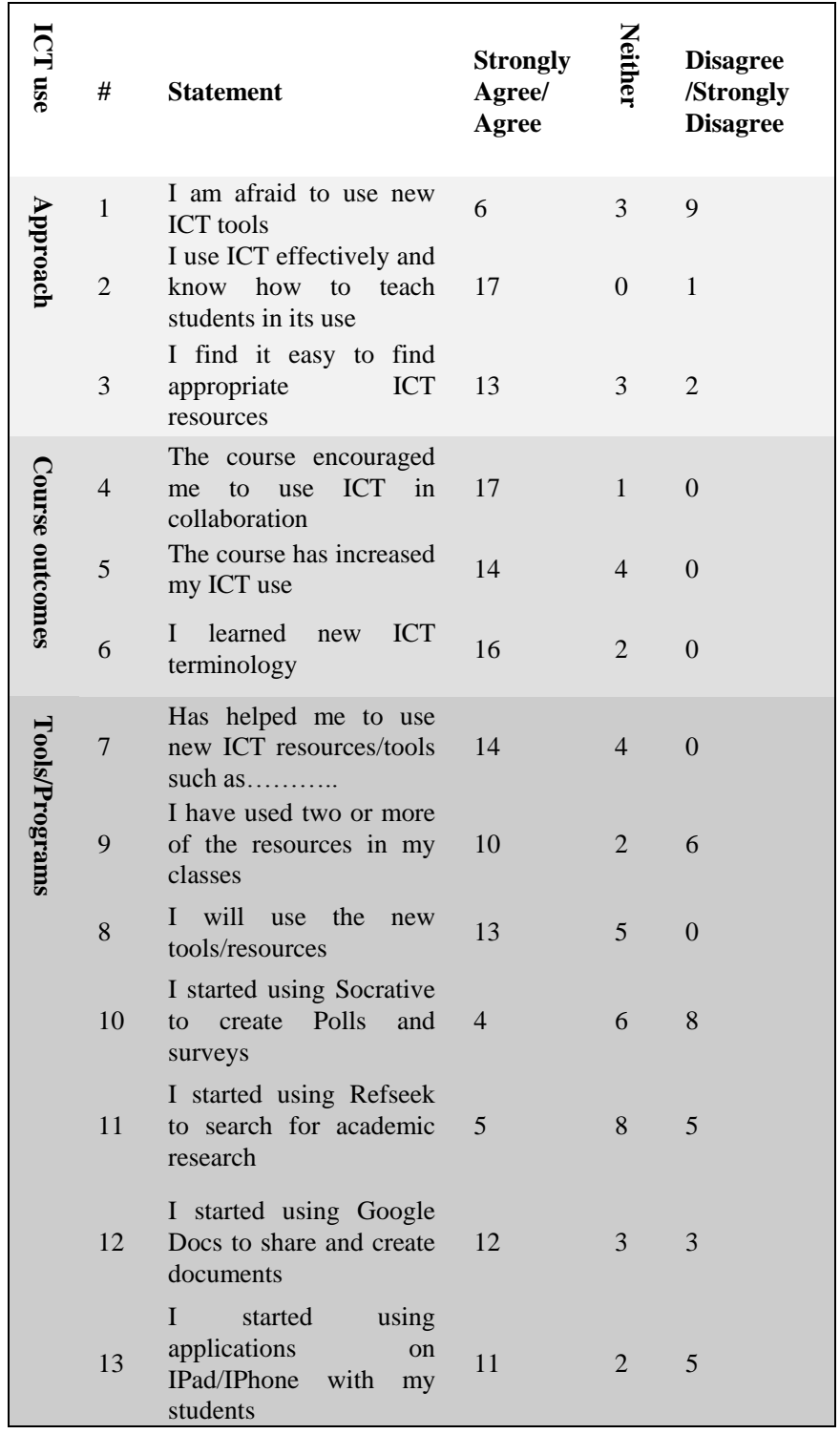

\section{Faculty Members' Opinion}

Section one of Table III showed the faculty members' opinion of the course learning, section one. They agreed that they found the course helpful in "non-work related task" and in "preparing coursework". In addition, they positively agreed that they have "gained adequate skills after the course". The faculty members' opinion on the understanding of the course, in section two, was also very positive. They seemed to understand the course clearly with only a few that showed little non understanding. This could be due to not understanding certain ICT applications or skills. The last section, three, discussed the faculty members' interest in recommending the ICT course and taking another similar one. Their attitude was positive as they thought that the course was "interesting and I (they) recommend it to colleagues". They were also "interested to take another related course in Kuwait" and abroad whether it was provided/sponsored by PAAET or another provider.
The faculty members reported considerable suggestions after the three day course that the researcher has noted. They had positive views regarding the 2.0 activity course as a number of them thought that it was "what we (they) really needed to boost our (their) skills", "I have gained a lot during the three days", and "the course should be repeated to others". The course therefore has updated their skills and they recommended it to their colleagues. Some commented that the course was "motivating and interesting" and that the "presenter was knowledgeable and motivated us (them) to learn". The "course content has met our expectations" a participant added the "presenter adjusted the content according to our skills needs" and they confirmed that "we learned more than what we had expected we will definitely make use of it in our classes". The course content and the presenter have motivated the faculty members to fully attend the course.

TABLE III: ICT SKILLS QUESTIONNAIRE AFTER A 2.0 COURSE - FACULTY'S OPINION

\begin{tabular}{|c|c|c|c|c|c|}
\hline 을. $\overline{\text { E }}$ & $\#$ & Statement & $\begin{array}{l}\text { Strongly } \\
\text { Agree/ } \\
\text { Agree }\end{array}$ & 要 & $\begin{array}{l}\text { Disagree/ } \\
\text { Strongly } \\
\text { Disagree }\end{array}$ \\
\hline \multirow{3}{*}{ 承. } & 1 & $\begin{array}{l}\text { I found the course } \\
\text { helpful in non-work } \\
\text { related task }\end{array}$ & 13 & 4 & 1 \\
\hline & 2 & $\begin{array}{l}\text { I found the course } \\
\text { helpful in preparing } \\
\text { coursework }\end{array}$ & 15 & 3 & 0 \\
\hline & 3 & $\begin{array}{l}\text { I have gained adequate } \\
\text { skills after the course }\end{array}$ & 17 & 1 & 0 \\
\hline \multirow{2}{*}{ 产: } & 4 & $\begin{array}{l}\text { There were parts of the } \\
\text { course I did not } \\
\text { understand }\end{array}$ & 3 & 3 & 12 \\
\hline & 5 & $\begin{array}{l}\text { I clearly understood all } \\
\text { the course }\end{array}$ & 14 & 0 & 4 \\
\hline \multirow[t]{5}{*}{ 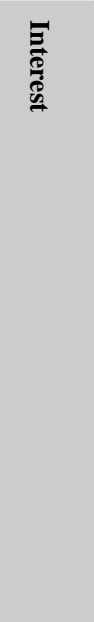 } & 6 & $\begin{array}{l}\text { The course was } \\
\text { interesting and I } \\
\text { recommend it to } \\
\text { colleagues }\end{array}$ & 17 & 1 & 0 \\
\hline & 7 & $\begin{array}{l}\text { I am interested to take } \\
\text { another related course } \\
\text { in Kuwait }\end{array}$ & 18 & 0 & 0 \\
\hline & 8 & $\begin{array}{l}\text { I am interested to take } \\
\text { another related course } \\
\text { abroad }\end{array}$ & 15 & 2 & 1 \\
\hline & 9 & $\begin{array}{l}\text { I would attend If } \\
\text { another similar ICT } \\
\text { course was provided } \\
\text { by PAAET }\end{array}$ & 17 & 1 & 0 \\
\hline & 10 & $\begin{array}{l}\text { I would attend If } \\
\text { another similar ICT } \\
\text { course was sponsored } \\
\text { by PAAET and given } \\
\text { by another provider }\end{array}$ & 18 & 0 & 1 \\
\hline
\end{tabular}

However, there were some drawbacks but not about the course, they were regarding PAAET (the local organiser and sponsor). The faculty commented that "PAAET does not organise such courses". A faculty member urged "I never attended a course like this here (locally) we need more courses like it". They confirmed that "PAAET should provide a budget for courses "it's cheaper than sending us abroad".

The data analysis has proved that training is needed to support the faculty in updating their skills and then delivering their lessons. The training should be related to the courses they teach and thus help the faculty to develop their skills and make use of it in training their students. 


\section{CONCLUDING REMARKS AND DISCUSSION}

It was concluded that providing courses such as this one or a course customized to the needs of the faculty increases motivation and generates challenges among them. The faculty showed a desire to use ICT during the ICT activity course and in their teaching. Fig. 2 illustrates the research process suggested in assessing the faculty members ICT skills.

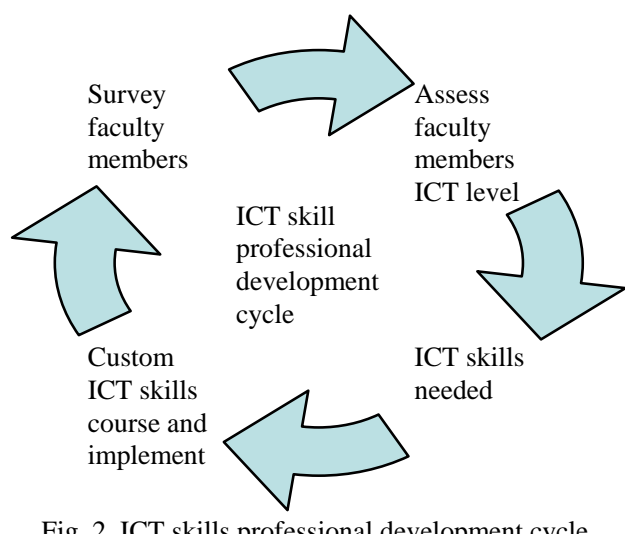

A limitation of this research was that the research sample was confined to a small number of the faculty members at one department; however the analysis of the result revealed a positive overall attitude.

The research finding showed that the faculty members ICT level was moderate as the majority had a basic ICT level and the appropriate skills level to apply to their work. They took the ICT course to know more about ICT, its use, and to develop their ICT skills. The course has updated their skills and they will apply them in their teaching and education. This supports the results of Thanuskodi that the faculty members at the Annamalai University stated that they knew and preferred to use ICT [2].

Regarding the faculty's ICT use the majority found using ICT effective and could teach their students on its use. The faculty agreed that the 2.0 activity course encouraged them to use ICT, they have gained new ICT terminology and that they used/will use new ICT resources/tools. This supports what Awan has found that training teachers and providing them with learning experiences affects their attitudes positively towards ICT use in teaching [12].

The faculty had positive opinion towards the course. They found the course helpful in work/non-work related tasks, gained adequate skills, understood the course clearly, thought it was interesting, would recommend it to their colleagues and they were interested to take another related course in Kuwait/abroad whether it was provided/sponsored by PAAET or another provider.

The results, clearly illustrated that offering the faculty with such a customized ICT course to fit their training needs and $\mathrm{PD}$ at their organization/employer resulted in positive learning experiences and an optimistic attitude. This aligns with the finding of Morentin, Amenabar and Lareki, who found that the faculty's preferred to be trained close to their working environments [1]. This was also suggested through the faculty's responses in the questionnaire, where they confirmed that their course training needs, ICT use and faculty's opinion were all positively met. In addition to, the qualitative data in which they commented that the course has updated their skills, motivated them and overall was useful.

It is recommended to encourage faculty members to make use of ICT in their daily routines and in the instructing of their courses. Faculty members might also consider a freer interchange of ideas with their students about the use of ICT in their teaching of them, thus hopefully engaging students through their own use of ICT, given that student's ICT skill levels may be more up to date and more practiced than their lecturers. This would not only improve faculty members' skills but it will also have a positive impact on their students to use ICT. PAAET, as an organization, should develop a well-planned policy to seek better PD opportunities for its faculty members based on their ICT skills needs, while making use of the suggested ICT PD cycle, Fig. 2, and customizing learning strategies/courses according to the needs of the organization and its faculty.

\section{REFERENCES}

[1] J. I. M. Morentin, N. Amenabar, and A. Lareki, "Faculty preferences for training modalities on ICTs," Revista de Psicodidáctica, vol. 16, no. 1, pp. 85-98, 2011.

[2] S. Thanuskodi, "Use of ICT for information creation among faculty members of Annamalai University, Tamil Nadu, India," International Journal of Library Science, vol. 1, no. 4, pp. 61-65, October 2012.

[3] Y. Göktaş, S. Yıldırım, and Z. Yıldırım, "Teachers educators' ICT competencies, usage, and perceptions," Gü, Gazi Eğitim Fakültesi Dergisi, vol. 29, no. 1, pp. 109-125, 2014.

[4] I. Gul, M. Arif, and M. J. Yousaf, "Adoption and diffusion of Information and Communication Technologies in higher education: using structural equation modelling," in Proc. 10th Int. Conference on Statistical Sciences, pp. 133-148.

[5] G. Tasie, "Competency-based trsaining needs analysis (TNA): An empirical study of Gulf University for science and technology, Kuwait," International Reasearch Journal of Management and Business Studies, vol. 1, no. 2, 2011.

[6] H. Buarki, M. Hepworth, and I. Murray, "LIS Students' ICT Skills in Kuwait: Perspectives of Employers, Teaching Staff and Students,' US-Chaina Education, vol 1, no. 1, pp. 89-97, 2011.

[7] H. Buarki, "ICT skills audit of the college of basic education faculty in Kuwait," presented at the Fourth Asian Connectedness Identity and Alienation in Literature Conference on Arts and Humanities (acah 2013), 4 April - 7 April, Osaka, Japan, April 2013.

[8] N. Z. Shuva., "Integrating ICT into university curriculum: A proposa for the faculty of arts,University of Dhaka, Bangladesh," in Proc Informing Science \& IT Education Conference (InSITE), pp. 487-502, 2013.

[9] S. A. Altun., E. Kalayc1, and Ü. AVCI, "Integrating ICT at the faculty level: A case study," TOJET: The Turkish Online Journal of Educational Technology, vol. 10 no. 4, pp. 230-240, October 2011.

[10] Y. K Usluel., P. Aşkar, and T. Baş, "A structural equation model for ICT usage in higher education," Educational Technology and Society, vol. 11, no. 2, pp. 262-273, 2008.

[11] Edtechteacher. (2014). [Online]. Available: http://edtechteacher.org/

[12] R. N. Awan., "What happens to teachers ICT attitudes and class room ICT use when teachers are made to play computer games?" International Journal of Information and Education Technology, vol. 4, no. 1, pp. 354-359, October 2011.

[13] N. Walliman, Social Research Methods, London: Sage Publications, 2006, ch. 7 pp. 168-170.

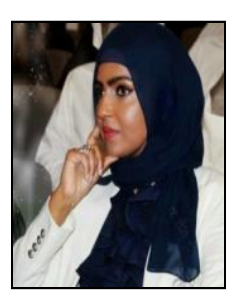

H. J. Buarki is an assistant professor at the DLIS, College of Basic Education, PAAET, Kuwait. She obtained a BA in English language and MLIS from Kuwait University. Dr Buarki holds an information science PhD from Loughborough University, UK. She has formally worked as an employee and the department head at the Libraries Administration, Kuwait University, and then as a TA at the DLIS. Her main research interest is in ICT education, curriculum evaluation and updating, ICT skills application and training of LIS faculty members and students. 